\title{
Studies on the Diabetic Syndrome of Idiopathic Haemochromatosis
}

\author{
G. Pozza and A. GHrooni* \\ Institute of Clinical Medicine, University of Milan, Italy \\ Received: June 19, 1967
}

Summary. Intravenous glucose tolerance test, intravenous tolbutamide test, insulin sensitivity and IL A have been investigated in a series of haemochromatosis patients. It appears that decreased carbohydrate tolerance and decreased insulin sensitivity are present in all subjects. - Serum IL A is within or above normal range and increases after tolbutamide administration. On the basis of the data shown, it is suggested that the decreased carbohydrate tolerance occurring in haemochromatosis is due to impaired peripheral glucose utilization, rather than to pancreatic insular insufficiency as postulated by several authors.

Etudes du syndrome diabétique des hémochromatoses idiopathiques

Résumé. On a étudié chez des malades atteints d'hémochromatose idiopathique, le test de tolérance au glucose intraveineux, le test au tolbutamide intraveineux, la sensibilité à l'insuline et l'activité insulinique du sérum (ILA). - Tous les sujets présentaient une diminution de la tolérance au glucose et une sensibilité diminuée à l'insuline. - L'activité insulinique du sérum était à des valeurs normales ou supranormales et augmentait après l'administration de tolbutamide. - Sur la base des résultats obte. nus, il est suggéré que la diminution de la tolérance au glucose qui se manifeste dans l'hémochromatose est due plutôt à une altération de l'utilisation périphérique du glucose qu'à l'insuffisance insulaire pancréatique, comme cela a été soutenu par plusieurs auteurs.

Untersuchungen des diabetischen Syndroms bei Patienten mit Hämachromatose

Zusammenfassung. In einer Serie von Patienten mit Hämochromatose wurde der intravenöse Glucosetoleranz test, der intravenöse Tolbutamidtest, die Empfindlichkeit gegen Insulin und die insulinähnliche Aktivität des Blutes (ILA) untersucht. - Alle Patienten zeigten eine verminderte Kohlenhydrat-Toleranz und eine herabgesetzte Insulinempfindlichkeit. - Die insulinähnliche Aktivität des Serums lag innerhalb oder oberhalb des Normalbereichs und stieg nach Gabe von Tolbutamid an. - Auf Grund der vorgelegten Ergebnisse kann man vermuten, daß die verminderte Kohlenhydrat-Toleranz bei Patienten mit Hämochromatose eher durch einen herabgesetzten peripheren Glucoseverbrauch als durch eine, von verschiedenen Autoren beschriebene Insuffizienz des Inselapparates verursacht wird.

Key-words: Diabetic syndrome, haemochromatosis, glucose tolerance, tolbutamide i.v. test, ILA, desferrioxamine, insulin sensitivity, insulin secretion

Table 1. Clinical data of subjects investigated

\begin{tabular}{|c|c|c|c|c|c|c|c|c|}
\hline Case & Age & Sex & $\begin{array}{l}\text { Fasting } \\
\text { blood sugar } \\
\mathrm{mg} / 100 \mathrm{ml}\end{array}$ & $\begin{array}{l}\text { Insulin } \\
\text { dose } \\
\mathrm{U} / 24 \mathrm{~h}\end{array}$ & $\begin{array}{l}\text { Plasma-Iron } \\
\mu \mathrm{g} \%\end{array}$ & $\begin{array}{l}\text { Desferal test } \\
\text { Urine-Iron } \\
\text { basal value }\end{array}$ & $4 \mathrm{~h}$ & second day \\
\hline 1 C.M. & 36 & $\mathbf{M}$ & 103 & 0 & 328 & 1287 & 13600 & 18360 \\
\hline $2 \mathrm{~B} . \mathrm{F}$. & 36 & $\mathrm{M}$ & 92 & 0 & 132 & 1287 & 12100 & 16480 \\
\hline 3 T.R. & 38 & M & 176 & 30 & 220 & 1368 & 19320 & 14060 \\
\hline 4 C.P. & 69 & $\mathbf{M}$ & 295 & 70 & 312 & 220 & 6600 & 5760 \\
\hline 5 C.M. & 73 & M & 242 & 45 & 192 & 1000 & 4267 & 6980 \\
\hline normal & & & $50-90$ & & $110 \pm 14$ & $505 \pm 305$ & $1179 \pm 298$ & $921 \pm 256$ \\
\hline
\end{tabular}

Desferal (Desferrioxamine Methasulphonate) was administered at the dosage of $1 \mathrm{~g}$ on the day of test. Urine was collected for three consecutive days, starting the day before the test.

Idiopathic haemochromatosis, also called iron storage disease, is often accompanied by decreased glucose tolerance, which eventually leads to overt diabetes.

Although the pathogenesis of the diabetic syndrome has not been fully clarified, the majority of the authors (Herbutr and Tamaki, 1946; Marble and BaILey, 1951 ; Kueckner et al., 1955 ; Joslnn, 1959 ; Peterson, 1960 ; Gutluox, J., 1963; Derot, 1963) who have studied haemochromatosis relate decreased carbohydrate tolerance with pancreatic insular fibrosis and consequent inadequacy of insulin secretion.

\footnotetext{
* with the technical assistance of ANNA GINI.
}

In five haemochromatosis patients that we have observed over the last two years, glucose tolerance, tolbutamide response, insulin sensitivity and serum insulin like-activity under various conditions have been studied, with the aim of elucidating the pathogenesis of the diabetic syndrome in these patients.

\section{Materials and Methods}

The diagnosis of idiopathic haemochromatosis was based upon clinical picture, liver biopsies, plasma iron levels and the Desferal test (WoHLER, 1964), (Table 1). 
None of the patients studied had a familial history of diabetes: glucose tolerance tests have been performed on several relatives of our patients, yielding normal values. Cases No. 1 and 2 had never received insulin before examination. Intravenous glucose tolerance test was performed by injecting in 3 min $0.5 \mathrm{~g}$ glucose per $\mathrm{kg}$ of body weight. Insulin-like activity (ILA) was determined before, and 10,20 and $60 \mathrm{~min}$ after glucose injection. Tolbutamide was injected intravenously at the dosage of $1 \mathrm{~g}$; ILA was determined at the same intervals as those described for glucose tolerance test. Insulin sensitivity was tested by injecting intravenously $0.1 \mathrm{U} / \mathrm{kg}$ body weight.

Blood glucose was determined according to HUGGEm and NIxon (1957). Serum ILA (dilution 1:5) was determined with the "pooled" rat epididymal fat pad method according to FroEsCH et al. $(1963) ;{ }^{14} \mathrm{CO}_{2}$ production from glucose-1. ${ }^{14} \mathrm{C}$ (Steinke et al., 1963) was measured as the metabolic index, instead of net gas exchange, as described in the original Froesch paper. The method employed has been fully described (Pozza et al., 1966).

\section{Results}

Fig. 1 shows glucose tolerance curves obtained by intravenous glucose administration. The glucose decay constant " $K$ " is also shown for each subject. It appears that all the patients but one (No.1) had decreased glucose tolerance.

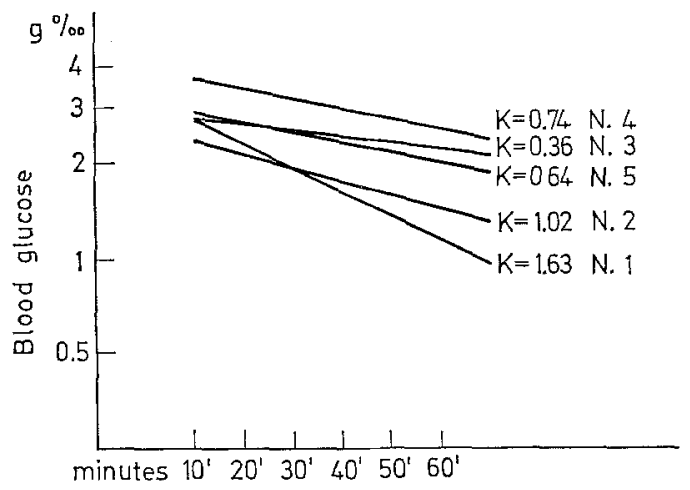

Fig. 1. Blood glucose after intravenous glucose load $(0.5 \mathrm{~g} / \mathrm{kg}$ body weight)

Fig. 2 shows the behaviour of blood glucose after tolbutamide administration, expressed as percentage change from the starting value; tolbutamide injection is followed by a slight and/or delayed fall of blood glucose, as usually occurs in diabetic patients (UNGER and MAdISON, 1958).

The values of ILA found in our patients in the fasting state on different days are shown in Table 2; it appears that the average serum ILA falls within the normal range in two cases, whereas it is above normal in three cases.

The behaviour of serum ILA in haemochromatosis patients, and in normal subjects after intravenous ad- ministration of glucose and tolbutamide, expressed as per cent increase above the fasting value, is shown in Fig. 3 and Fig. 4, and the absolute values of ILA appear in Table 2, in which control values are also reported.

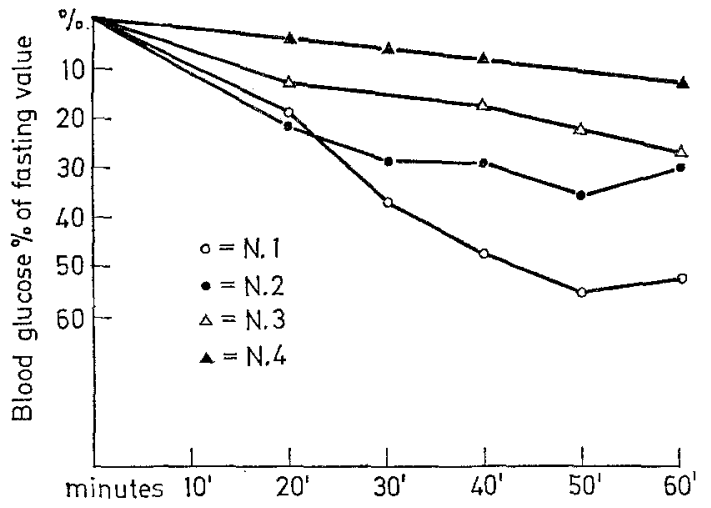

Fig. 2. Blood glucose after intravenous tolbutamide ad. ministration (1 g)

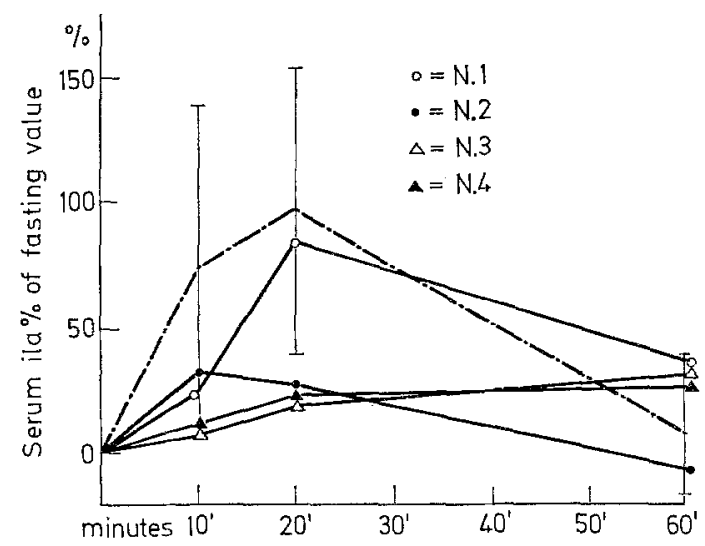

Fig. 3. Serum ILA response to intravenous glucose load. Dotted line represents control values $1 \pm$ S.D.

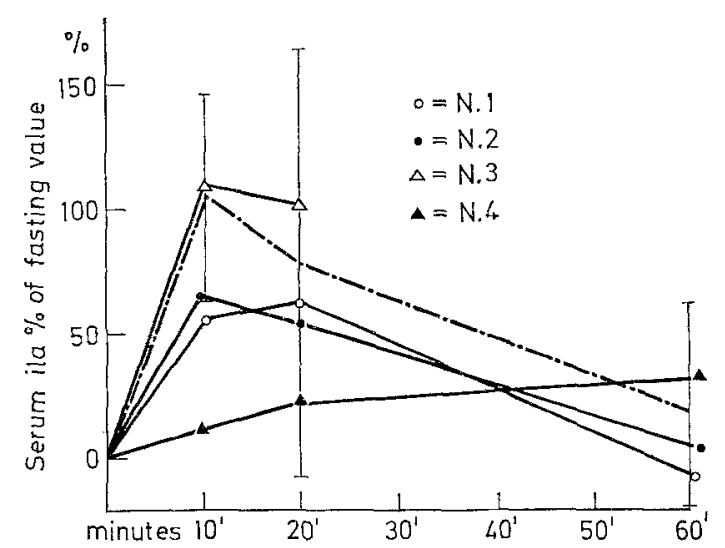

Fig. 4. Serum ILA response to intravenous tolbutamide $(1 \mathrm{~g})$. Dotted line represents control values \pm S.D.

During the intravenous glucose tolerance test the behaviour observed reproduced the pattern described for diabetic patients, with a response which was de- 
layed and quantitatively slight, whereas tolbutamide injection induced a pronounced increase of ILA in three patients out of four.

Fig. 5 shows the pattern of blood glucose after the intravenous administration of insulin $(0.1 \mathrm{U} / \mathrm{kg})$. It appears that in all the cases there was a decreased insulin sensitivity.
Furthermore, serum ILA appeared to be within or above the normal range. In previous papers by other authors (STEINKE et al., 1962; SCHOEFFLING et al., 1965) it had been shown that in depancreatized or hypophysectomized-depancreatized animals, ILA did. not disappear as was expected, but it only fell to about one half of the starting value. These data indeed cast

Table 2. Serum ILA in haemochromatosis patients ( $\mu U / 0.2 \mathrm{ml})$

\begin{tabular}{lcccccccc}
\hline Case & \multicolumn{3}{c}{ Intravenous glucose tolerance test } & \multicolumn{4}{c}{ Intravenous tolbutamide test } \\
\hline & fasting & $10 \mathrm{~min}$ & $20 \mathrm{~min}$ & $60 \mathrm{~min}$ & fasting & $\mathbf{1 0}$ min & $20 \mathrm{~min}$ & $20 \mathrm{~min}$ \\
\hline 1 & 70 & 85 & 130 & 96 & 98 & 154 & 159 & 87 \\
2 & 120 & 156 & 152 & 112 & 125 & 205 & 192 & 130 \\
3 & 175 & 192 & 211 & 230 & 160 & 347 & 320 & - \\
4 & 215 & 238 & 272 & 277 & 175 & 208 & 215 & 241 \\
5 & 255 & - & - & - & - & - & - & - \\
\hline control (10) & 112 & 230 & 254 & 143 & 103 & 213 & 172 & 113 \\
S.D. & \pm 25 & \pm 93 & \pm 97 & \pm 49 & \pm 35 & \pm 86 & \pm 69 & \pm 31 \\
\hline
\end{tabular}

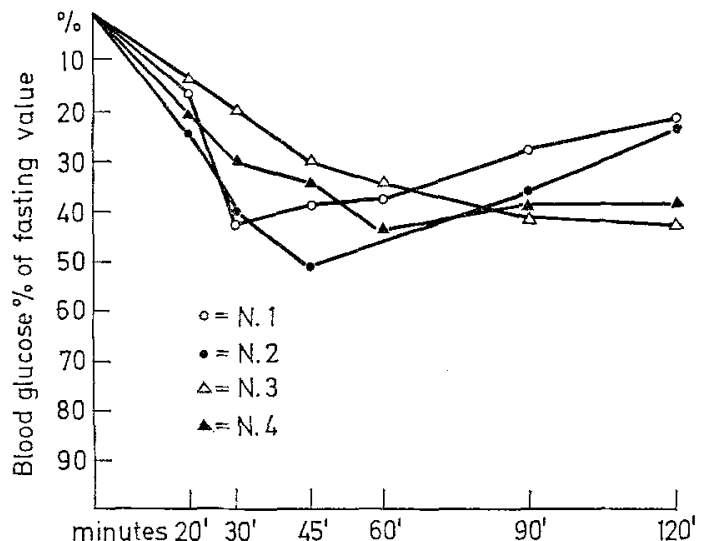

Fig. 5. Blood glucose after intravenous administration of insulin $(0.1 \mathrm{U} / \mathrm{kg}$ body weight)

\section{Discussion}

From the data shown it appears that in idiopathic haemochromatosis a decreased glucose tolerance is evident, which can appear with the full picture of diabetes mellitus as in cases No. $3-4-5$, or can be detected by means of intravenous glucose tolerance or tolbutamide intravenous test, as in cases No. 1 and 2.

Several authors have suggested that the diabetic syndrome of haemochromatosis could be related to pancreatic fibrosis with insular insufficiency; in which case the clinical picture should be similar to that observed after total or subtotal pancreatectomy, that is to say it should be characterized by a marked sensitivity to exogenous insulin, and decreased levels of ILA (Goldberg and Egdahr, 1961; Slater et al., 1961; STEINkE et al., 1962; LmonARDs et al., 1962).

This seems not to be the case in our patients; in all of them insulin sensitivity was decreased, including the patients who had never received insulin previously, ruling out that a decreased insulin sensitivity could be related to development of insulin antibodies. a doubt on the reliability of serum ILA values as true information of circulating insulin. Nevertheless, the fact that in our patients ILA was not even slightly decreased, confirms that decreased insulin secretion from the pancreas does not play a primary role in the clinical conditions under investigation.

The intravenous administration of tolbutamide was followed by a significant increase of serum ILA. Although the entity of ILA increase after tolbutamide is still a controversial matter (YALOW et al., 1960; Pfetffer, 1961; Polosa et al., 1964), it seems that the results obtained show that the insular system of our patients was able to respond to stimulation by sulphonylurea.

Intravenous glucose load induced a less marked increase of ILA, with the exception of case No. 1, the only one which showed a normal $K$ value. It seems therefore possible to suggest that factors other than insular insufficiency could play a role in the diabetic picture of haemochromatosis.

Among the factors involved the following should be considered: a) existence of diabetes mellitus independent of or superimposed on haemochromatosis; b) insulin resistance not due to insulin antibodies; c) decreased peripheral utilization of glucose.

On the basis of the data shown and of current knowledge, it seems impossible to prove or rule out any of these hypotheses, although the absence of a familiarity for diabetes, and the normal glucose tolerance proved in the relatives of our patients, seem to reject the first one.

As far as insulin resistance is concerned, it should be recalled that no inhibitors of the synalbumin type have been detected in the serum of haemochromatosis patients (VALLANCE-OWEN, 1964).

It has been recently demonstrated (GHIDONI et al., 1966; Pozza et al., 1966) that Desferrioxamine, an iron chelating agent with high affinity for iron, used in the treatment of haemochromatosis, induces a significant increase of glucose utilization by rat diaphragm and of 
glucose metabolism and lipid synthesis by adipose tissue, possibly mediated through removal of iron from the cell.

This could lead to the hypothesis that increased iron storage in the tissues, as occurs in haemochromatosis, decreases peripheral glucose utilization, with consequent impaired carbohydrate tolerance not related to insulin deficiency, at least in the initial stage of the disease. This could also explain the occurrence of decreased insulin sensitivity, as confirmed in these patients by several other authors (BovLIN, 1948; EskIND and FraCkIIN, 1953; GoILLON and DELUMEAN, 1961; Michon et al., 1961; DaRnaud et al., 1963). Eventually, in the later stages, lack of insulin due to chronic pancreatitis could supervene, with further deterioram tion of the diabetic syndrome.

\section{References}

Boulun, R.: Les troubles de la glycorégulation dans le diabète bronzé. Bull. Ass. Études physiopath. Foie et Nutrit. 6, $40-44$ (1948).

Darnaud, C., J., Deinard G. Moreau, R. Volsin et J. Bertrand: L'insulino-résistance au cours de l'hémo. chromatose. XXXIV Congr. Français de Medec., p. 427 Paris: Masson 1963.

DÉrot, M.: Conclusion - XXXIV Congr. Français Med., p. 453 Paris: Masson. 1963.

EsKIND, I.B., and W. FrackLIN : Insulin resistant diabetes mellitus associated with hemochromatosis. Ann. Int. Med. 38, 1295-1036 (1953).

Froesch, E.R., H. Burgi, E. B. Railscier, P. Baliy, and A. LaBHART: Antibody suppressible and non suppressible insulin-like activities in human serum and their physiologic significance. An insulin assay with adipose tissue of increased precision and specificity. - J. clin. Invest. 42, 1816-1834 (1963).

Ghidoni, A., E. SANest, and G. Pozza: Effect of Desfer. rioxamine Methansulfonate on glucose uptake by rat epididymal adipose tissue. Proc. Soc. exp. Biol., N. Y. 121, 1039 - 1041 (1966).

GoLDBER(, H.L., and R.H. Edga.tu: Studies suggesting the extrapancreatic production of substances with insulin-like activity. Fed. Proc. 20, 190 (1961).

Gothion, J., et G. Delumiear : Le diabète de l'hémochromatose. Rev. frane. Endocr. 2, 339-347 (1961).

- Le mécanisme pathogénique du diabète dans l'bémochromatose. XXXIV Congrès Français de Méd., p. 409. Paris: Masson 1963.

Herrbutt, P., and H. Tamaki: Cirrhosis of the liver and diabetes as related to hemochromatosis. Ann. J. clin. Path. 16, 640-650 (1946).

HuGGETT, A.S., and D.A. NTxoN : Enzymic determination of blood glucose. Biochem. J. 66, 12 (1957).

Joscis, E.P.: The treatment of diabetes mellitus, p. 103. Philadelphia: Lea \& Febiger, 1959.

KLECKNER, M.S. Jr., R.M. KARK, I.A. BAKER, A.Z. Chapman, E. Kaptan, and T.J. Moore: Clinical features pathology and therapy of hemochromatosis. J. amer. med. Ass. 157, $1471-1476$ (1955).
LAONARDS, J.R., B.R.LANDAU, and G. BaRTSCH: Assay of insulin and insulin-like activity with rat epididymal fat pad. J. Lab. clin. Med. 60, 552-570 (1962).

Marble, A., and C.C. BameY: Hemochromatosis. Ann. J. Med. 11, 590-599 (1951).

Mrchon, P., A. Lazcan, C. Hurters, et P. Vert: Hémochromatose et insulino-résistance. Eifficacité d'un traitment par ACTH. Le Diabète 9, 128 - 132 (1961).

Peterison, R.E.: Hemochronatosis. In: The metabolic basis of inherited disease, p. 839. New York: MeGraw Hill 1960.

Pferrear, E.F.: Sul meccanismo d'azione di sostanze antidiabetiche orali (Solfaniluree, bignanidi). Atti del II Simposio Nazionale sul Diabete, p. 365. Catania: 1961 .

Polosa, P., L. Motxa, F. Sorge, e E. TuRRisi: Comportamento dell'attivita similinsulinica dopo carico endovena di Tolbutamide nel soggetto metabolicamente sano e nel diabetico. Acta Diabetologica Latina 1, $32-38$ (1964).

Pozza, G., A. Ghidoni, G. Sorgato, e E. Santest: Studio del metabolismo glicidico nel tessuto adiposo e nel muscolo in rapporto all'azione di un agente chelante, la desferrioxamina. Acta Diabetologica Latina 3, 381 - 391 (1966).

_ - , e E. SANESI: La determinazione dell'attività simi. linsulinica del siero umano con il metodo del tessuto adiposo epididimale del ratto. Metabolismo 2, 305-324 (1966).

Sohomfinat, K., H. Dimsonundet, R, Petzold, J. Bexter, E.F. Predffer, A. SIREK, H. GeERling, and O.V. Srazk: Serum insulin-like activity in hypophysectomized and depancreatized (Houssay) dogs. Diabetes 14, 658-662 (1965).

Slater, J.D.H., C. Samaak, R. Fraser, and D. StiltMAND : Immunological studies with circulating insulin. Brit. med. J. 1961I, 1712-1715 (1961).

Streinke, J., A. SiREK, V. LaURIS, F.D.W. LukENs, and A. E. RENoLD : Measurement of small quantities of insulin-like activity after pancreatectomy. J. clin. Invest. 41, 1699-1707 (1962).

-, J. Soetidner, A. Camerint-Davalos, and A.E. ReiNOLD: Studies on serum insulin-like activity (ILA): prediabetes and early overt diabetes. Diabetes 12, $502-507(1963)$.

UNGER, R.H., and L.L. Madisor: Comparison of response to intravenously administered sodium tolbutamide in mild diabetic and nondiabetic subjects. J. clin. Invest. 37, 627-630 (1958).

VALLANCE-OWEN, J.: Synalbumin insulin antagonism and diabetes.Ciba Foundation - Colloquia on Endocrinology. 15, 217-234 (1964).

WoHrfR, F.: Diagnosis of iron storage diseases with Des. ferrioxamine (Desferal Test). Acta haemat. 32, 321-337 (1964).

YaIow, R.S., H. BLACK, M. VIrLAzON, and S.A. BrzSON: Comparison of plasma insulin levels following administration of tolbutamide and glucose. Diabetes 9,356362 (1960).

Dr. G. Pozza

Institute of Clinical Medicine

University of Milan

Milan, Italy 